\title{
ILMAN LÄMPÖTILAN MITTAAMISESTA ERILAISIA SÄTEILYSUOJUKSIA KÄYTTÄEN
}

\author{
YRJö Pessi \\ Hallakoeasema, Pelso
}

Saapunut 18. 10. 1954

Kun hallakoeasema otti tutkimusohjelmaansa kasviston ilmaston minimilämpötilanmittaukset eri paikkakunnilla, oli tarkoituksena ennen sitä löytää mittaustapa, jolla saataisiin mahdollisimman oikeita arvoja ja joka olisi käytännössä helppo suorittaa.

Mittareilta, joita käytetään tämänkaltaisiin mittauksiin, vaaditaan lähinnä kaksi ominaisuutta: mittarien tulee häiritä lämpöoloja mahdollisimman vähän ja niiden säteilyvirheen tulee olla mahdollisimman pieni.

Mittarien valikoima tämänlaatuisiin tutkimuksiin on pieni, sillä ainoa kysymykseen tuleva mittarityyppi on alkoholialinarvomittari. Säteilyvirhe tämän kokoisissa mittareissa saattaa olla huomattava. Tämän vuoksi suoritettiin tutkimuksia erilaisia säteilysuojuksia käyttäen sopivan säteilysuojuksen löytämiseksi ja säteilyvirheen merkityksen selvittämiseksi.

Vertailevia minimilämpötilanmittauksia suoritettiin neljällä eri mittaustavalla, jotka olivat:

Budig-suojus mittarin nestesäiliön yläpuolella

sama suojus nestesäiliön alapuolella

lieriömäinen säteilysuojus nestesäiliön ympärillä

ilman säteilysuojusta.

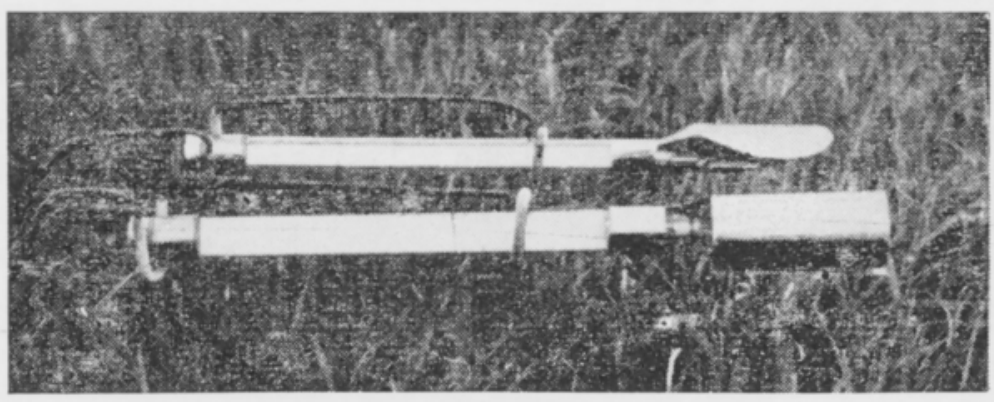

Takana Budig-suojuksella, edessä lieriömäisellä säteilysuojuksella varustettu lämpömittari heinänurmen päällä.

Behind: liquid reservoir provided with Budig shield; below: the same provided with cylindrical radiation shield over the grass field. 
Säteilysuojukset tehtiin $0.3 \mathrm{~mm}: n$ paksuisesta kiiltävästä alumiinipellistä. Budig-suojus, läpimitaltaan $7 \mathrm{~cm}$ suuruinen ympyränmuotoinen levy, asetettiin $1 \mathrm{~cm}$ päähän lämpömittarin lämpökappaleesta. Lieriömäisen suojuksen pituus oli $7 \mathrm{~cm}$ ja halkaisija $3 \mathrm{~cm}$. Tutkimuksessa käytettiin alinarvolämpömittareita $(\mathrm{R}$. Fuess, jaoitus $1 \mathbf{2}^{\circ}$ ) ja oli jokaisesta mittaustavasta kolme kerrannaista. Mittauspaikalla kasvoi lyhyt nurmi. Mittarit sijoitettiin noin $10 \mathrm{~cm}$ korkeudelle kasviston ylärajasta. Mittarit luettiin $0.1^{\circ}$ tarkkuudella arvioimalla $1 / 2{ }^{\circ}$ pienemmät asteen osat. Mittaukset suoritettiin tyyninä, selkeinä öinä, jolloin mittaustavan erilaisuus tulee parhaiten ilmi ja jollaisia nimenomaan hallayöt ovat.

Mittaustulokset esitetään taulukossa 1. Kerrannaisten poikkeamat olivat samana yönä korkeintaan $0.3^{\circ}$.

Budig-suojuksella varustetun mittarin säteilyvirhe määritettiin Assmannin tuuletuspsykrometriä vertailuinstrumenttina käyttäen. Säteilyvirheellä tarkoitetaan sitä lämpötilan poikkeamaa ilman todellisesta lämpötilasta, mikä aiheutuu mittarin vastaanottamasta tai sen lähettämästä lämpösäteilystä. Kun mittarin vastaanottama lämpösäteily on suurempi kuin sen lähettämä, on säteilyvirhe positiivinen ja mittari osoittaa siis liian korkeaa lämpötilaa. Kun mittarin lähettämä lämpösäteily ylittää sen vastaanottaman, on säteilyvirhe negatiivinen ja mittari osoittaa liian alhaista lämpötilaa. Säteilyvirhettä määritettäessä mitattiin

Taulukko 1. Minimilämpötilat yhdeltätoista hallayöltä erilaisia mittaustapoja käyttäen.

Table 1. Minimum temperatures during 11 frosty nights measured by different methods.

\begin{tabular}{|c|c|c|c|c|}
\hline $\begin{array}{c}\text { Vuorokausi } \\
\text { Date }\end{array}$ & $\begin{array}{l}\text { Budig-suojus } \\
\text { yläpuolella } \\
\text { Budig shield } \\
\text { above }\end{array}$ & $\begin{array}{l}\text { Lieriömäinen } \\
\text { suojus } \\
\text { Cylindrical } \\
\text { shield }\end{array}$ & $\begin{array}{l}\text { Ilman suo- } \\
\text { justa } \\
\text { Without } \\
\text { shield }\end{array}$ & $\begin{array}{l}\text { Budig-suojus } \\
\text { alapuolella } \\
\text { Budig shield } \\
\text { below }\end{array}$ \\
\hline $6.5 .-51$ & -2.0 & -2.2 & -2.4 & -2.8 \\
\hline 7. $5 .-51$ & -5.4 & -5.8 & -6.4 & -7.0 \\
\hline 8. $5 .-51$ & -3.8 & -4.4 & -5.1 & -6.0 \\
\hline 9. $5 .-51$ & -7.4 & -8.0 & -8.5 & -9.8 \\
\hline $10.5 .-51$ & -4.0 & -4.5 & -5.3 & -6.0 \\
\hline 11. $5 .-51$ & -4.0 & -4.7 & -5.2 & -6.2 \\
\hline $23.5 .-51$ & -4.0 & -4.6 & -5.3 & -6.2 \\
\hline 8. $6 .-51$ & -4.1 & -4.6 & -5.3 & -6.1 \\
\hline 9. $6 .-51$ & -3.5 & -4.1 & -4.9 & -5.7 \\
\hline $23.6 .-51$ & -2.5 & -2.8 & -3.5 & -4.2 \\
\hline 15. $6 .-54$ & -4.6 & -5.0 & -5.4 & -5.9 \\
\hline $\begin{array}{l}\text { Keskimäärin } \\
\text { Average }\end{array}$ & -4.12 & -4.61 & -5.21 & -5.99 \\
\hline \multicolumn{2}{|c|}{$\begin{array}{l}\text { Pyöristettynä } \\
0.1^{\circ} \text { tarkk. } \\
\text { To the nearest } 0.1^{\circ} \mathrm{C} \text {. }\end{array}$} & -4.6 & -5.2 & -6.0 \\
\hline
\end{tabular}


Taulukko 2. Säteilyvirhe käytettäessä Budig-suojusta mittarin yläpuolella

Table 2. Error due to radiation using the Budig shield above the liquid reservoir.

Tuulen nopeus $\mathrm{m} / \mathrm{sek} \ldots \ldots \ldots$
Wind velocities $m . / \mathrm{sec} . \ldots \ldots$
$\begin{aligned} & \text { Säteilyvirhe } \mathrm{C}^{\circ} \ldots \ldots \ldots \ldots \ldots \ldots \\ & \text { Error due to radiation }{ }^{\circ} \mathrm{C} \ldots \ldots\end{aligned} \quad$ - $\ldots .4$

tuulen voimakkuus hyrräanemometrillä. Mittarit sijaitsivat $0.7 \mathrm{~m}$ korkeudella. Säteilybilanssi oli $-0.11 \mathrm{gcal} / \mathrm{cm}^{2} \times \min$. ja se mitattiin säteilytasemittarilla. ${ }^{1}$

Taul. 1 ja 2 havaitaan, että lähinnä oikeat ilman lämpötilat saadaan käytettäessä Budig-suojusta mittarin lämpökappaleen yläpuolella, toiseksi lähinnä lieriömäistä säteilysuojusta käyttäen, sen jälkeen ilman säteilysuojusta, lukemien poiketessa eniten käytettäessä Budig-suojusta lämpökappaleen alapuolella.

Hallakoeasemalla otettiin käyttöön lieriömäinen säteilysuojus minimilämpötiloja mitattaessa lähinnä käytännöllisistä syistä. On nimittäin erittäin tärkeätä, että vertailevissa lämpötilanmittauksissa kaikki mittaukset suoritetaan samalla tavoin. Kun mittarit joutuvat olemaan jatkuvasti peltoviljelyksillä, pysyy lieriömäinen säteilysuojus hyvin paikallaan kovassakin tuulessa. Sen sijaan Budig-suojus saattaa muuttaa tuulessa asentoaan sekä murtua poikki kannastaan. Mittarien hoitaminen helpottuu näin ollen lieriömäisiä säteilysuojuksia käytettäessä ja vaatii vähemmän huolellisuutta, millä on oma merkityksensä käytännössä.

S U M M A R Y :

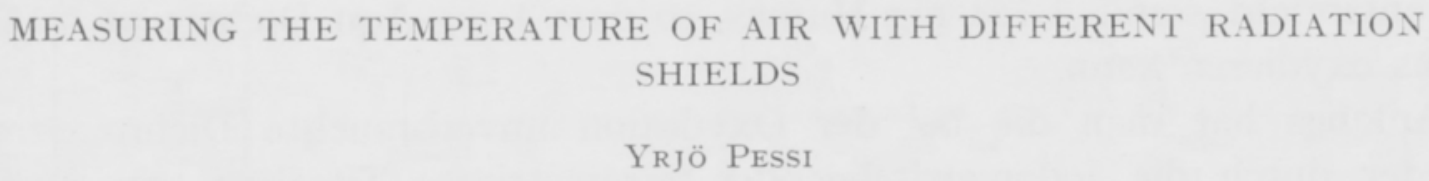

Frost Research Station, Pelso

Measurements of the minimum air temperature above a grass field have been made at the Frost Research Station during frosty nights using different radiation shields. In comparison with thermometers where the Budig shield was used above the liquid reservoir, those with cylindrical radiation shields gave, on average, values $0.5^{\circ} \mathrm{C}$. lower, those without a shield values $1.1^{\circ}$ lower, and those with the Budig shield below the liquid reservoir values $1.9^{\circ}$ lower (Tab. 1). The error due to radiation when the Budig shield was used was $-0.4^{\circ}$ and $-0.2^{\circ}$ with wind velocities of 0.3 and $1.5 \mathrm{~m} . / \mathrm{sec}$. and with radiation balance -0.11 g.cal. $/ \mathrm{cm}^{2} \times$ minute.

The most suitable method in practice was considered to be the cylindrical radiation shield, though nearly correct minimum temperatures are obtained using the Budig shield above the liquid reservoir.

1 Franssila. M. 1953. A Net Radiation Instrument with Constant Ventilation. Eripainos Geophysica 4: 3 . 